\title{
POLA ASUH ANAK DALAM SERAT PALIATMA
}

\author{
Nurhidayati \\ FBS Universitas Negeri Yogyakarta
}

\begin{abstract}
Abstrak
This research study is intended to describe child-rearing patterns in Serat Paliatma by KGPAA Mangkunagara IV.

The source of the data was Serat Paliatma, consisting 18 stanzas in pupuh Dhandhanggula (the Dhandhanggula song). The data were collected by means of orthographic transliteration, translation, paraphrase, and careful reading and rereading. The data were analyzed descriptively. The data validity was assessed through semantic validity. The data reliability was assessed through reproducibility.

The research findings show that there are two child-rearing patterns in Serat Paliatma, namely (1) the one related to religious norms, and (2) the one related to values in life. The former includes acceptance to what is given, gratefulness, and devotion. Meanwhile, the latter covers asceticism, affection, unity, obedience, loyalty to the country, and responsibility.
\end{abstract}

Key words: child-rearing pattern, serat, pupuh

\section{A. Pendahuluan}

\section{Latar Belakang Masalah}

Peranan orang tua sangat dominan dalam usaha mempersiapkan anaknya menjadi anak yang berkualitas. Lingkungan pertama yang mempengaruhi perkembangan anak adalah keluarga. Di dalam keluarga anak diasuh orang tuanya dengan menanamkan berbagai sikap, nilai, aturan-aturan, agar m e m punyai kepribadian yang baik. Pola pengasuhan orang tua yang diterima anak dari orang tuanya merupakan fondasi bagi kepribadian anak untuk selanjutnya.

Anak dalam pandangan hidup masyarakat Jawa merupakan penerus keluarga yang diharapkan dapat mengharumkan nama keluarga dan mengubur aib keluarga. Hal tersebut tercermin dalam ungkapan Jawa yang berbunyi: " dadia anak kang bisa mikul dhuwur mendhem jero", artinya jadilah anak yang dapat mengangkat harkat dan martabat keluarga seta dapat menguburkan aib keluarga. Dengan demikian sangat penting arti pengasuhan anak untuk membentuk kepribadian anak yang mampu mengangkat harkat dan martabat keluarganya.

Pengasuhan anak dalam masyarakat Jawa banyak diajarkan oleh para pujangga dalam bentuk wejangan yang menguraikan tentang individu yang ideal. Media untuk mengekspresikan wejangan tersebut salah satunya adalah sastra wulang. Salah satu pujangga yang produktif menulis sastra wulang adalah KGPAA Mangkunagara IV dengan karyakaryanya yang sangat terkenal, antara lain: Wedhatama, Wulang Pawestri, Warayagnya, Darmawasita, Sriyatna, Tripama, Paliatma dan lain-lain. Dengan membaca, membedah, dan memahami kandungan isi karya-karya sastra piwulang-nya akan menambah wawasan dan 
dapat dijadikan pedoman dalam membentuk kepribadian yang luhur. Serat $\mathrm{Pa}$ liatma merupakan salah satu karya yang terdapat dalam Karangan Pilihan Karya KGPAA Mangkunagara IV. Naskah tersebut berisi tentang informasi tentang larangan-larangan untuk anak. Hal tersebut tersirat dari judul naskah tersebut, pali artinya pepali, awisan 'larangan' dan atma artinya anak; paliatma artinya larangan untuk anak (Kamajaya, 1992: 166). Informasi tentang bagaimana mengasuh anak yang baik merupakan hal yang penting dalam upaya penanggulangan kemerosotan moral di Indonesia. Fenomena tersebut dapat dilihat dari maraknya pembunuhan, perkosaan, pembakaran dan pengrusakan yang tidak bertanggung jawab. Berdasarkan uraian tersebut maka perlu dikaji bagaimanakah pola asuh anak dalam Serat Paliatma.

\section{Tujuan Penelitian}

Penelitian ini bertujuan untuk mendeskripsikan pola asuh anak yang terdapat dalam Serat Paliatma karya KGPAA Mangkunagara IV.

\section{Landasan Teori}

\section{a. Karya Sastra Wulang}

Karya sastra merupakan wujud transformasi pengalaman jiwa, ide, dan imajinasi pujangga yang berupa fakta dan fiksi, demikian pula karya sastra mencerminkan sifat, watak, dan kegiatan manusia di dalam masyarakat. Sekaligus sifat, watak, dan aktivitas pelaku karya sastra dapat dijadikan pelita pemberi penerangan kepada masyarakat pada jamannya dan masa berikutnya (Padmopuspita, 1990: 39)

Pemanfaatan karya sastra untuk kehidupan di jaman modern dipertegas oleh Suwondo (1994: 6) yang menyatakan bahwa karya sastra yang dibuat pada masa lalu mempunyai potensi un- tuk dimanfaatkan pada jaman modem, apabila karya sastra itu ditafsirkan sesuai dengan cara berfikir modern. Berdasarkan beberapa pendapat tersebut dapat diasumsikan bahwa karya sastra merupakan wujud transformasi pengalaman jiwa, ide, dan imajinasi pengarang yang mencerminkan kehidupan pada masa tertentu dan dapat dimanfaatkan untuk kehidupan masa datang.

Salah satu pemanfaatan karya sastra pada masa sekarang ialah sebagai alat mendidik. Hal ini sesuai dengan salah satu fungsi karya sastra menurut Lenin dalam Luxemburg (1992: 25) diungkapkan bahwa karya sastra tidak hanya mencerminkan kenyataan, sastra harus turut membangun masyarakat; sastra harus berperan sebagai guru, dan harus menjalankan fungsi didaktik.

Salah satu usaha mendidik generasi penerus dalam masyarakat Jawa dilakukan dengan memberikan wejangan berkaitan dengan nilai-nilai kehidupan yang luhur. Wejangan tersebut banyak yang digubah dalam bentuk karya sastra., yang selanjutnya oleh Suryadi disebut sebagai sastra wulang (1995:11). Salah satu bentuk gubahan sastra wulang tersebut disampaikan dalam bentuk tembang. Tembang merupakan sastra tradional dalam budaya Jawa yang diciptakan bukan secara kebetulan. Kehadirannya dimaksud untuk tujuan yang jelas, yaitu: untuk pengejawantahan ekspresi pikiran penulis yang berkaitan dengan situasi dan kondisi masyarakat; dan untuk mengekpresikan jiwa seninya. Tanggapan terhadap situasi dan kondisi masyarakat dapat berupa saran dan kritik demi perbaikan menurut visinya, sedangkan untuk mengekpresikan jiwa seninya digubah dengan bahasa yang indah, mengikuti guru lagu, guru wilangan, dan purwakanthi tertentu.

Karya sastra wulang yang sebagian besar digubah dalam bentuk puisi (tem- 
bang). Untuk pengambilan data penelitian maka perlu dilakukan langkahlangkah seperti parafrase, pemaknaan, dan inferensi. Berkaitan dengan pemaknaan dalam karya sastra khususnya puisi, Nurgiyantoro (1998: 32) berpendapat sebagai berikut: "Dalam memaknai karya sastra khususnya puisi dikenal tahap-tahap yang disebut tahap heuristik dan hermeneutik". Kerja heuristik merupakan pembacaan karya sastra pada pemaknaan semiotik tingkat pertama, yang merupakan pemahaman makna seperti yang dikonvensikan oleh bahasa. Hasil pemahaman maknanya berupa makna harfiah. Selanjutnya berdasarkan makna tersurat dilanjutkan pemahaman dengan hermeneutik yang membutuhkan kompetensi sastra dan budaya. Hasil pemaknaannya berupa kata tersirat.

\section{b. Pola Asuh Anak dalam Masyarakat Jawa}

Pola asuh adalah cara-cara pengaturan tingkah laku anak yang dilakukan oleh orang tua sebagai suatu perwujudan dan pembentukan kepribadian anak (Aliyah, 1987: 7).

Gerungan mendefinisikan pola asuh sebagai suatu cara sikap orang tua dalam memimpin anaknya sehingga akan mempengaruhi pertumbuhan kepribadian anak-anaknya (Gerungan, 1978: 7).

Pola asuh merupakan cara orang tua dalam memberikan asuhan pada anak-anaknya atau cara interaksi antara orang tua dengan anak-anaknya. Pola asuh orang tua adalah pola asuh ayah dan ibu secara ideal dan terdapat bahu membahu dalam melaksanakan tanggung jawab sebagai orang tua dan mampu memenuhi tugasnya sebagai pendidik (Simanjuntak, 1984: 130).

Berdasarkan beberapa pendapat tersebut maka dapat dirangkum bahwa pola asuh adalah suatu cara orang tua dalam mendidik, memimpin, membimbing, membina serta mengatur tingkah laku anak-anaknya sebagai salah satu wujud tanggung jawab orang tua dalam membentuk kepribadian anak.

Pola asuh anak dalam masyarakat Jawa sedikit banyak dipengaruhi oleh keluarga yang telah madeg dhewe, merupakan unit sosial baru yang pada umumnya disebut rumah tangga (house hold). Kesatuan sosial yang mengurusi ekonominya sendiri ini merupakan keluarga inti, keluarga batih atau nuclear family. Anggota dari keluarga inti terdiri dari ayah, ibu serta anak-anak (Suparto dkk, 1990: 27).

Rumah tangga inti dengan anggota keluarga dapat mempengaruhi proses sosialisasi. Orang tua dalam keluarga inti, memperoleh peranan dalam membantu anak untuk mempelajari cara-cara bertingkah laku yang sesuai dengan lingkungannya. Setiap orang tua harus menyadari bahwa baik buruknya tabiat, akhlak anak-anaknya itu bergantung baik buruknya pendidikan yang diberikan mereka kepada anak-anaknya sejak si anak kecil (Faried M, 1980: 139).

Sistem nilai yang berkaitan dengan masalah pola asuh anak menurut Suparto, dkk (1990: 54) meliputi norma-norma agama, nilainilai hidup, sopan santun dan susila. Sistem nilai yang berkaitan dengan norma agama antara lain: berdoa, sholat, puasa dan tawakal. Sistim nilai yang berkaitan dengan nilai-nilai hidup meliputi prinsip-prinsip kerukunan, hormat, taat, narima, rila, dan sabar. Sistem nilai yang berkaitan dengan sopan santun meliputi: taat kepada orang tua, andhap asor, ramah terhadap teman dan tetangga (sanak kadang), rajin bekerja membantu orang tua, berbicara yang baik dan berbahasa yang baik. Sedangkan sistem nilai yang berkaitan dengan susila meliputi: larangan melanggar aturan, berhati-hati dalam bergaul, dan 
berpegang teguh pada aturan.

Sistem nilai yang berkaitan dengan norma-norma agama sejak dini perlu ditanamkan dalam diri anak. Agama memberikan suatu perspektif bagi manusia untuk menafsirkan seluruh kejadian yang dialami setiap saat. Dalam fungsinya sebagai kerangka penafsiran terhadap kenyataan sosial yang bersifat faktual, agama dianggap sebagai suatu sistem kultural. Manusia yang mempercayai dan menghayati ajaran agama akan memperoleh suatu kerangka acuan untuk memberi makna seluruh kejadian yang dialaminya sepanjang hidup manusia (Sutjiatiningsih, 1999: 92).

Sistim nilai dalam masyarakat Jawa yang berkaitan dengan kerukunan, hormat, taat, rila, dan mawas diri menurut Suseno (2001: 53) merupakan perwujudan sikap lahir dan ba tin untuk mencegah terjadinya perpecahan ataupun konflik-konflik yang terbuka.

Nilai sopan santun dalam masyarakat Jawa merupakan salah satu penentu penghargaan terhadap seseorang. Hal tersebut terlihat jika seseorang bersikap tidak sopan terutama terhadap orang tua maka akan disebut urakan atau nranyak. Sopan santun merupakan salah satu cara orang Jawa menghormati orang lain. Sikap hormat tersebut disebut ngajeni.

Nilai yang berkaitan dengan susila dalam masyarakat Jawa perlu ditanamkan pada anak sejak dini (Suparto, dkk. 1990: 48). Anak diarahkan dengan baik agar jangan nerak paugeran melanggar peraturan dan nerak wewaler melanggar peraturan yang telah ditetapkan masyarakat maupun agama. Dalam bertingkah laku anak senantiasa diajari untuk kukuh gondhelan waton hams berpegang teguh pada aturan-aturan yang ada baik itu aturan-aturan Tuhan yang terdapat dalam agama ataupun aturan yang dibuat berdasarkan kesepaka tan bersama dalam masyarakat.

\section{B. Metode Penelitian}

Subjek dalam penelitian ini adalah Serat Paliatma karangan KGPAA Mangkunagara IV. Serat Paliatma digubah dalam satu pupuh tembang Dhandhanggula.

Teknik pengumpulan data dilakukan melalui tahap-tahap:

(1) Transliterasi ortografi, yakni penggantian jenis tulisan huruf demi huruf dari abjad yang satu ke abjad yang lain sesuai standar Ejaan Yang Disempumakan (Baroroh dkk, 1985: 65). Dalam hal ini tulisan huruf Jawa diubah ke dalam huruf Latin. Transliterasi ortografi dimaksudkan untuk mempermudah pemahaman isi serta memperjelas fenomenafenomena yang dibutuhkan.

(2) Menerjemahkan data, dalam tahap ini menggunakan metode terjemahan bebas. Baroroh, dkk (1985: 66) menyatakan bahwa dalam menerjemahkan dapat digunakan metode bebas apabila mutlak perlu menjaga segala lapisan dalam bahasa asalnya.

(3) Membuat parafrase, hal ini dilakukan untuk mempermudah pemahaman isi naskah yang digubah dalam bentuk tembang Dhandhanggula.

(4) Melakukan pembacaan secara cermat dan berulang-ulang untuk memahami dan menginterpretasikan baik kata, frasa, larik, pada, maupun pupuh dalam Serat Paliatma

Analisis data yang digunakan dalam penelitian ini adalah analisis deskriptif. Furchan (1982: 415) mengatakan bahwa analisis deskriptif adalah melukiskan variabel atau kondisi 'apa yang ada' dalam situasi tertentu. Analisis deskriptif dalam penelitian ini bertujuan untuk memberikan gambaran tentang pola asuh anak yang terkandung dalam Serat Paliatma. Validitas data ditimbang melalui validitas semantis, sedangkan reliabilitas didasarkan pada reproducibility. 


\section{Hasil Penelitian dan Pembahasan \\ 1. Hasil Penelitian}

Pola asuh anak yang terdapat dalam Serat Paliatma mencakup dua hal. Pertama, pola asuh anak yang berkaitan dengan norma-norma agama meliputi nrima ing pandum, bersyukur, dan bertakwa. Kedua, pola asuh yang berkaitan dengan nilai-nilai hidup meliputi: prihatin, kasih sayang, kerukunan, ketaatan, bertanggung jawab, berbakti pada negara.

\section{Pembahasan}

a. Pola Asuh Anak yang Berkaitan dengan Norma-Norma Agama

Data pola asuh anak yang berkaitan dengan norma agama dijaring berdasarkan data-data yang mempunyai karateristik perilaku manusia dalam hidup yang berhubungan dengan bagaimana ia melaksanakan perintah-perintah Tuhan.

\section{1) Narima ing Pandum}

Narima ing pandum artinya menerima apa yang telah diberikan oleh Tuhan, narima ing pandum bukan berarti putus asa tetapi membatasi diri untuk berbuat di luar aturan agar dapat lebih menerima (Bratawidjaya, 1997: 91). Sikap narima ing pandum tidak hanya diterapkan pada saat mendapatkan kesusahan saja, namun juga pada saat mendapatkan kebahagiaan. Sikap narima ing pandum mengarahkan seseorang untuk bersikap tabah dan tidak putus asa pada saat mendapatkan kesusahan. Begitu pula pada saat mendapatkan kebahagiaan agar dapat mensyukurinya dan tidak lupa diri.

Sikap narima ing pandum dalam Serat Paliatma merupakan salah satu sikap yang diajarkan orang tua kepada anak dalam usahanya mengasuh anak. Orang tua mengarahkan anak- anaknya agar bersikap narima ing pandum pada saat mendapatkan kebahagiaan. Anak dididik agar mengetahui bahwa semua kebahagiaan itu berasal dari pertolongan Tuhan. Hal tersebut dapat dilihat dari data berikut:

mulane putraningwang, den narimeng pandum, yeku pitulunging Suksma, ingsun enget sangkaning kamulyan $k a k i, \ldots$

'maka anakku, terimalah apa adanya, itulah pertolongan Tuhan, ingatlah asal mula kebahagiaan,...'

Orang tua mengasuh anaknya dengan mendidik agar bersikap narima ing pandum. Hal tersebut dapat dijadikan sebagai salah satu usaha agar anak tidak mudah frustasi. Anak diarahkan agar percaya takdir Tuhan. Manusia diciptakan di dunia dengan tulisan nasib masing-masing. Hidup menderita a taupun bahagia sudah menjadi ketetapan Tuhan yang melekat dalam diri manusia. Dengan demikian anak mampu menerima keadaan dirinya sepenuhnya dan tidak mudah frustasi dalam menghadapi tantangan hidup. Hal tersebut dapat dijadikan antisipasi timbulnya tindak-tindak kejahatan yang dilakukan oleh pemuda yang frustasi. Fenomena tersebut, pada masa sekarang sedang marak terjadi.

\section{2) Bersyukur}

Manusia di dalam menjalani kehidupannya sering sekali lupa akan nikmat yang telah diberikan Tuhan secara berlimpah. Dalam menikmati kebahagiaan terkadang sampai lupa diri, tidak tahu asal dari kebahagiaan tersebut. Dan pada saat mendapatkan penderitaan mudah putus asa, merasa Tuhan tidak menyayanginya.

Kebahagiaan dan penderitaan merupakan nikmat Tuhan yang harus disyukuri. Sikap bersyukur merupakan salah satu wujud pola asuh anak yang terdapat dalam Serat Paliatma. Hal terse- 
but dapat dicermati dari data berikut: lega bungah sukur ing Hyang Sukma, leganingsun awit dene, katekan panedhengingsun, bungahingsun dulu sireki, sukurku ing Hyang Suksma, dene saduruftgipun, sun mulih mring kalanggengan, bisa weruh ing tumanjanira sami, uripmu aneng donya,...

'puas, bahagia dan syukur kepada Tuhan, puasnya hati saya karena tercapai permohonan saya, bahagia saya, karena melihat kamu (sekarang), syukurku kepada Tuhan karena sebelum saya meninggal duni, masih dapat melihat kebahagiaanmu di dunia,...'

Orang tua mengasuh anaknya dengan limpahan kasih sayang. Harapan dan doa senantiasa dipanjatkan untuk kebahagiaan anaknya. Maka ketika anaknya dapat hidup dengan bahagia ha tinyapun merasa sangat bahagia. Kebahagiaan tersebut tidak lupa dinikmatinya dengan rasa syukur kehadirat Tuhan. Dalam hal ini orang tua mengasuh anaknya dengan mendidik agar anak pandai bersyukur atas nikmat yang diberikan Tuhan kepadanya. Sikap pandai bersyukur juga perlu pada saat mendapatkan penderitaan agar anak tidak putus asa. Penderitaan merupakan jalan Tuhan memberikan berbagai pengalaman hidup agar manusia dapat menjalani kehidupan dengan lebih baik. Dalam penderitaan pasti ada hikmah yang berguna bagi kehidupan selanjutnya.

\section{3) Bertakwa}

Sikaptakwamerupakan perwujudan dari sikap menjalankan segala perintah Tuhan dan menjauhi segala laranganNya. Tuhan adalah pencipta, penguasa alam semesta, pemberi kehidupan dan penghidupan semua makhluknnya. Manusia sebagai salah satu makhluk yang paling sempurna mempunyai kewajiban untuk bertakwa kepada-Nya. Salah satu kewajiban yang harus dijalankan adalah menjalankan ibadah.

Berkaitan dengan pengasuhan anak oleh orang tua tentang ketaqwaan dalam Serat Paliatma, orang tua mengajarkan anaknya untuk bertaqwa yang diwujudkan dalam bentuk sembah. Satusatunya yang wajib disembah ialah Tuhan Yang Maha Pengasih. Hal tersebut dapat dicermati dari data berikut:

wanti-wanti wulanging sudarmi, darmatama temen tinumanna, manungsa mangka sembahe, maring Hyang Maha Agung, ingkang agung asih dumadi,... 'ingat-ingatlah ajaran tentang kewajiiban yang baik, kewajiban yang utama bersungguh-sungguh dan selalu lakukanlah, manusia hanya beribadah, kepada Tuhan Yang Maha Agung, yang mengasihi umatnya,...'

Dalam masyarakat jawa sikap takwa direalisasikan dengan sikap Manunggaling Kawula Gusti. Untuk dapat menyatu dengan Tuhan harus menjalankan empat tingkatan ibadah, yaitu: sembah raga, sembah kalbu, sembah jiwa, dan sembah rasa. Sembah raga

direalisasikan dengan menjalankan syariat agama yang dipeluk. Bagi orang Islam menjalankan sholat lima waktu. Sembah kalbu direalisasikan dengan membersihkan diri dari keinginankeinginan hati yang bersifat duniawi. Sembah jiwa direalissikan dengan menguasai panca indera dan nafsunafsu yang mengelilingi. Sedangkan sembah rasa direalisasikan dengan menghidupkan rasa jati dalam diri manusia. Empat tingkatan ibadah yang diwujudkan dalam sembah tersebut ditujukan hanya kepada Tuhan Sang Pencipta. Dalam usaha mengasuh anak, orang tua mendididik bahwa satusatunya yang paling 
hakiki untuk disembah hanyalah Tuhan Yang Maha Esa sebagai penguasa hidup dan mati serta pemberi kehidupan dan penghidupan.

\section{b. Pola Asuh Anak yang Berkaitan dengan Nilai-nilai Hidup}

Pola asuh anak yang berkaitan dengan nilai-nilai hidup dijaring berdasarkan perilaku manusia yang berkaitan dengan bagaimana ia hidup di dalam masyarakat dengan baik.

\section{1) Laku Prihatin}

Laku prihatin disebut pula dengan tirakat yaitu pantang atau mengurangi makan, minum, tidur dan sebagainya guna mencapai tujuan tertentu, diantaranya mendapatkan ketenangan jiwa dan mendekatkan diri kepada Tuhan. Tirakat ini cenderung bersifat pada halhal yang batiniah (Marsono, 1999: 316).

Dalam Serat Paliatma laku prihatin merupakan salah satu pola asuh yang diberikan oleh orangtua kepada anaknya. Anak diarahkan agar mengetahui betapa orang tua sangat menyayanginya sehingga ia rela melakukan laku prihatin untuk anaknya agar dapat hidup bahagia. Hal tersebut dapat dilihat dari data berikut :

sira ngger sumurupa, den-pracayeng kalbu, (ng)gon-sun mrihatinken sira,... kamu anak(ku) ketahuilah, dan percayalah di ha ti, tentang usahaku menjalankan laku prihatin untuk$\mathrm{mu}, \ldots$

Dalam masyarakat Jawa laku prihatin sering dilakukan ketika seseorang menginginkan sesuatu terutama berkaitan dengan ketenangan jiwa. Mereka yakin dengan mendekatkan diri kepada Tuhan maka segala keinginannya dapat terkabul. Demikian pula orang tua berusaha mengupayakan kebahagiaan anaknya, ia mendekatkan diri kepada Tuhan den- gan menjalankan laku prihatin. Salah satu hal yang sangat membahagiaan orang tua ialah ketika ia dapat menyaksikan anaknya hidup dengan bahagia. Kecintaannya kepada anak membuat ia rela melakukan usaha seberat apapun demi kebahagiaan anaknya.

Laku prihatin diajarkan kepada anak oleh orang tua dengan tujuan agar anak tidak mengumbar hawa nafsu. Hidup dengan mengumbar hawa nafsu tidak akan mendatangkan kebahagiaan, karena akan merugikan dirinya sendiri ataupun orang lain. Laku prihatin dapat dijadikan alternatif untuk menumbuhkan pengendalian diri pada anak. Hawa nafsu manusia perlu dikendalikan. Jika anak mampu mengendalikan hawa nafsunya maka ia tidak akan bertindak yang merugikan dirinya sendiri ataupun orang lain. Ia mampu menata kehidupannya dengan lebih baik untuk mencapai kebahagiaan.

\section{2) Kasih Sayang}

Kasih sayang merupakan bentuk dari rasa suka, senang, cinta dan kasih yang diberikan seseorang tanpa mengharapkan imbalan. Usaha orang tua membesarkan anak-anaknya disertai kasih sayang yang berlimpah. Salah satu bentuk kasih sayang orang tua kepada anak dalam Serat Paliatma ialah ketulusan orang tua mendoakan kebahagiaan untuk anak-anaknya. Anugrah yang telah diterimanya diharapkan juga dapat dinikmati oleh anak-anaknya. Pola asuh anak tentang kasih sayang orang tua kepada anak tersebut dapat dilihat pada indikator berikut ini:

nora pegat panedhengsun batin, muga sira akatumusana, kanugrahaningsun angger,...

tidak berhenti doaku dalam hati, semoga kamu akan menemui, anugrah (seperti) aku,... 
Pola asuh anak tentang kasih sayang orang tua kepada anak juga tercermin dari doa agar anaknya mendapatkan kenikmatan hidup di dunia dan akhirat. Orang tua senantiasa memohon agar anaknya tercapai keinginannya dengan selamat, panjang umur, mendapatkan anugrah dan kemuliaan, sejahtera, terhindar dari bencana dan selalu dilindungi Tuhan, serta selamat dunia akhirat. Pola asuh tersebut terdapat dalam data berikut:

ing wusana pandongaku kaki, marang sira kabeh atmajaningwang, ingkang rahayu sedyane, dinawakna kang umur, winantuwa nugraha jati, sinungana kamulyan, prapta kang kinayun, kang marang ing karaharjan, nir bancana rinakseng Maha Suci, selamet donya kerat.

'akhirnya doaku, kepadamu semua anakku, selamatlah keinginanya, panjang umur, mendapatkan anugrah sejati, diberi kemuliaan, tercapai yang diinginkan, sejahtera, terhindar dari bencana dan dilindungi Tuhan, selamat dunia akhirat.'

Pengasuhan anak tentang kasih sayang orang tua kepada anaknya sangat penting. Dalam diri anak akan timbul keyakinan bahwa is sangat dicintai orang tuanya. Limpahan kasih sayang yang diberikan pada anak akan menjadikan hubungan yang penuh kasih diantara keduanya. Selain itu anakpun dapat bersikap hormat dan menghargai atas segala jasa orang tua kepada dirinya, selanjutnya berdampak timbulnya sikap berbakti kepada orang tua. Jika hubungan yang penuh kasih antara anak dan orang tua dapat terjalin dengan baik maka tindak-tindak kejahatan antara keduanya tidak akan terjadi. Pada saat ini fenomena kekerasan dalam rumah tangga sudah banyak terjadi, antara lain: pembunuhan dan penganiayaan orang tua oleh anaknya, pemerkosaan ibu oleh anak, ataupun tindak kekerasan lain yang dilakukan anak kepada orang tuanya. Dengan adanya pengasuhan anak tentang kasih sayang orang tua kepada anak, maka hubungan yang penuh kasih dapat terbina dengan baik sehingga dapat dijadikan salah satu alternatif mengantisipasi timbulnya kekerasan dalam rumah tangga yang dilakukan oleh anak.

\section{3) Kerukunan}

Kerukunan adalah tuntutan untuk mencegah segala kelakuan yang dapat menimbulkan konflik terbuka. Tujuan dari sikap rukun ialah keselarasan sosial dan keadaan damai (Suseno, 1984: 52).

Sikap rukun dalam Serat Paliatma merupakan salah satu sikap yang diajarkan orang tua kepada anak dalam rangka memberikan pengasuhan. Salah satu bentuk pengasuhan tersebut berupa larangan melakukan hal-hal yang dapat menimbulkan konflik. Hal ini dapat dicermati dari data berikut:

waleringsun marang sira kaki, aywa limut padha estokena, kaya kang sun tutur kiye, dhihin ywa karya giyuh, kaping kalih ywa karya isin, katri ywa karya sira rusuh ing pangrengkuh ping pat away mrih piala, mring wang dengwang ping lima sira ywa kardi, nepsune galihing Wang.

'laranganku padamu anakku, jangan sampai lupa, kerjakanlah dengan sungguh-sungguh seperti yang saya nasehatkan ini, pertama jangan berbuat hal yang membuat sedih, kedua jangan berbuat hal yang memalukan, ketiga jangan berbuat kerusuhan, keempat jangan berbuat sesuatu yang tercela di depan mukaku, kelima kamu jangan membuat hatiku marah..' 
Berdasarkan data tersebut dapat diketahui pengasuhan anak untuk mewujudkan kerukunan, orang tua memberikan larangan kepada anak antara lain: pertama berbuat hal yang membuat sedih, kedua berbuat hal yang memalukan, ketiga berbuat kerusuhan, keempat melakukan perbuatan tercela, kelima berbuat yang dapat menimbulkan marah.

Kesedihan salah satunya dapat disebabkan karena hati seseorang merasa terluka oleh perbuatan orang lain. Efek dari perasaan yang terluka ini seseorang merasa tersakiti sehingga memungkinkan timbul dendam. Adanya dendam dapat menimbulkan konflik sehingga kerukunan tidak dapat tercipta. Demikian juga perbuatan yang memalukan dan menimbulkan kemarahan dapat memancing emosi seseorang sehingga orangpun berkeinginan untuk membalas dendam. Perbuatan kerusuhan juga dapat menimbulkan konflik karena berakibat mengganggu keselarasan sosial. Perbuatan tercela merupakan bentuk tindakan pelanggaran norma dalam masyarakat. Jika seseorang melanggar norma maka ia akan mendapatkan sangsi dari masyarakat. Hal tersebut akan berdampak terganggunya ketentraman warga dan memberikan dampak turunnya harkat dan martabat keluarganya sendiri. Dengan demikian orang tua perlu memberikan pengasuhan anak tentang usaha menjaga kerukunan agar dapat mengantisipasi timbulnya konflik yang mengakibatkan perpecahan. Usaha menjaga kerukunan tersebut direlisasikan dengan tidak melakukan perbuatan yang membuat seseorang sedih, marah, dan malu. Selain itu juga tidak melakukan perbuatan tercela dan berbuat kerusuhan.

Bentuk larangan lainnya berkaitan dengan pengasuhan anak tentang kerukunan adalah larangan berbuat jahat.
Perbua tan jahat tersebut dalam Serat Paliatma digambarkan sebagai tindakan mencelakakan sesama dengan menggunakan sarana hal-hal yang kasar maupun halus, ataupun dari hal lainnya baik lahir maupun batin yang menimbulkan keburukan bagi sesamanya Hal ini dapat dicermati dari data berikut:

aja ana ala ing alangan sami, ingkang mawa sarana, saking wadhag tuwin saking remit, sumawana saking liyanira, lair batin kang agawe durta sasaminipun,...

jangan berbuat jahat untuk mencelakakan sesama, dengan sarana, dari yang kasar maupun hal-hal yang kecil (halus), atau dari hal lain, lahir dan batin yang akan menjadikan keburukan bagi sesamanya,...'

Pandangan hidup masyarakat Jawa salah satunya adalah mengutamakan kerukunan. Hal tersebut tercermin dalam ungkapan Jawa yang berbunyi: "Rukun agawe santosa crah agawe bubrah". Kerukunan akan menciptakan kekuatan yang tangguh sedangkan perpecahan akan menimbulkan kehancuran. Demikian juga keluarga yang harmonis harus mampu menciptakan kerukunan antar warganya. Untuk mewujudkannya orang tua perlu memberikan pengasuhan kepada anaknya tentang usaha mewujudkan kerukunan dalam keluarga. Dalam Serat Paliatma hal tersebut direalisasikan dengan ajaran agar anak selalu rukun dengan saudaranya baik laki-laki maupun perempuan. Hal tersebut dapat dicermati dari data berikut.

...den arukun saeka kapti, lawan sadulurira kang estri myang jalu, ...rukunlah dalam satu kehendak, dengan saudaramu baik wanita maupun laka-laki,...

Rukun mengandung usaha terus menerus oleh semua individu untuk 
bersikap tenang satu sama lain dan menyingkirkan unsur-unsur yang memungkinkan timbulnya perselisihan dan keresahan (Suseno,2001: 39). Orang tua memberikan pengasuhan kepada anak berkaitan dengan kerukunan salah satunya dapat dijadikan usaha mengantisipasi tindak-tindak kejahatan dalam keluarga. Sekarang ini marak sekali tindak-tindak kejahatan dalam keluarga yang dilakukan oleh anak maupun orang tua, antara lain: perkosaan, pembunuhan, penganiyaan, perebutan warisan dan lain sebagainya. Hal tersebut dapat terhindari jika warga dalam keluarga tersebut mampu membina kerukunan dan saling memahami keinginan masing-masing anggota keluarga untuk mencapai kata mufakat bersama. Keadaan rukun dalam satu kehendak tersebut merupakan kondisi ideal untuk mencapai keselaran hidup bersama.

\section{4) Ketaatan}

Masyarakat Jawa dalam menjalankan kehidupannya diatur oleh aturanaturan yang telah menjadi kesepakan - bersama. Aturan-aturan tersebut dapat berupa norma maupun adat istiadat yang jika dilanggar akan mendapatkan sangsi atau hukum. Harkat dan martabat keluarga akan tercemar jika seseorang melanggar aturan-aturan yang telah disepakati tesebut. Hal ini berdampak dalam pengasuhan anak, orang tua selalu mengajarkan agar anak menaati aturanaturan yang ada dalam masyarakat. Pengasuhan anak tentang ketaatan ini juga ditegaskan dalam Serat Paliatma agar anak tidak melanggar hukum dalam mencari nafkah. Hal tersebut dapat dicermati dari data berikut.

lamun datan mangkonoa kaki, yekti karam lamun sira pangan, awit ninggal mring khukume, tetep kanistanipun, anyamahken prabawa kaki, nyudakaken derajat,... 'jika tidak begitu anakku, pasti hafam jika kamu makan, karena meninggalkan hukumnya, tetap nista, menurunkan kewibawaanmu, mengurangi derajat,

Dalam menjalankan kehidupannya masyarakat Jawa selalu berusaha perpegang pada aturanaturan yang telah disepakati bersama. Hal ini tercermin dalam ungkapan "Urip iku mawa paugeran supaya ora geblinger"; artinya hidup ini harus dengan aturan agar tidak tersesat atau keliru. Demikian juga dalam mencari nafkah harus tetap menjaga aturanaturan yang ada dalam masyarakat.

Nafkah yang dihasilkan dengan cara melanggar hukum adalah haram jika dimakan. Sedangkan perbuatan mencari nafkah dengan melanggar aturan atau hukum adalah perbuatan nista. Jika hal tersebut dilakukan akan menurunkan kewibawaan dan mengurangi derajat seseorang dalam kehidupan masyarakat.

\section{5) Berbakti pada negara}

Negara sebagai tanah kelahiran telah memberikan berbagai penghidupan. Berbagai hal telah dimanfaatkan untuk kesejahteraan warga. Bahkan terkandang pemanfaatan tersebut berakibat pengrusakan terhadap kelestarian alam sekitar. Pemerintah selalu berusaha berjuang meningkatkan kemakmuran bangsa melalui pembangunan di berbagai sektor. Kewajiban untuk membangun negara bukan hanya menjadi kewajiban pemerintah saja tetapi juga seluruh warganya. Dalam masyarakat Jawa kecintaan terhadap negara diungkapkan dengan ungkapan" Rawe-rawe rantas malangmalang tuntas"; artinya apa (siapa) saja yang menghalang-halangi akan dimusnahkan. Sedangkan usaha pembelaan terhadap negara diungkapkan dengan "Sadumuk bathuk sanyari 
bumi" artinya pengorbanan apapun demi membela negara akan dikakukan bahkan sampai ma tipun rela".

Dalam Serat Paliatma, pengasuhan anak yang berkaitan dengan ajaran berbakti pada negara direfleksikan dengan 6 kewajiban bagi seseorang yang mendapatkan kemulyaan dari negara. Hal tersebut terkandung dalam data berikut.
...umurupa wajibing wong ingkang sami, antuk kamulyanira, saking praja panggonaning lair, ingkang dhingin nut wiradatira, pindho nyangkul segawene, katri sakadaripun, (m)biyantoni harjan- ing nagri, kaping pat angowela, mring pitunanipun, ping lima melu rumeksa, pakewuhe kaping nem amurinani, ru- sake prajanira,...
ketahuilah kewajiban orang yang mendapat kemulyaan dari negara tempat kelahiran, pertama sesuai dengan kehendakmu, kedua kerja- kan tanpa pilih-pilih, ketiga mem- bantu kesejahteraan negara semam- punya, keempat jangan berbuat yang merugikan (negara), kelima ikut menjaga ketentraman, dan kee- nam menjaga dan membela negara dari kerusakan,...'

Seseorang yang telah mendapatkan kemuliaan hidup dari negara mempunyai kewajiban berbakti pada negaranya. Adapun caranya yaitu: Pertama, sesuai dengan kehendak. Seseorang berbakti pada negara akan lebih menyenangkan jika sesuai dengan kehendak dan keahliannya. Kedua, bekerja tanpa pilih-pilih, apapun yang dibutuhkan negara suka atau tidak harus dikerjakan. Ketiga, membantu kesejahteraan negara semampunya sehingga tidak merasa terbebani. Keempat, jangan melakukan perbuatan yang berakibat merugikan negara. Kelima, ikut menjaga ketentraman. Dan keenam, ikut membela neg- ara dan menjaganya dari kerusakan. Jika keenam hal tersebut dilaksanakan dengan baik maka kesejahtearaan dan kedaulatan negara dapat terjamin.

\section{6) Bertanggung jawab}

Saudara tua di dalam masyarakat Jawa merupakan salah satu orang yang harus dihormati atau diajeni. Mengapa saudara tua harus dihormati? Hal ini sebenarnya berkaitan dengan tanggung jawab yang harus dipenuhinya terhadap orang tua maupun kepada saudara yang lebih muda. Sebagai saudara tua ketika orang tuanya sudah meninggal maka is yang harus menggantikan peran orang tua tersebut. Tanggung jawab orang tua untuk mengasuh anak sampai dewasa digantikan olehnya. Tanggung jawab saudara tua untuk mengasuh adikadiknya juga diajarkan dalam Serat Paliatma. Adapun datanya sebagai berikut: ...amung kari arinta pangeran prangwadana sakadange kang dadi galihingsun, dene padha maksih alit-alit kangmangka yuswaningwang wus sewidak taun, iya lamun menangana, diwasane yen ora iku masthi, dadi ing karyanira. hanya tinggal adikmu pangeran Prangwadana dan saudaramu, yang menjadi pikiran saya, karena masih kecil-kecil sedangkan usiaku sudah 60 tahun, syukur nanti masih bisa menyertai sampai dewasa, tetapi jika tidak itu menjadi tanggung jawabmu.'

Selanjutnya dalam Serat Paliatma juga dijelaskan bagaimana pengasuhan saudara muda (adik) yang dilakukan saudara tua menggantikan tanggung jawan orang tua. Hal tersebut dapat dicermati dari data berikut:

Awit iki tumekaning benjing, ingsun titip Para arinira, prangwadana sakadange, reksanen ayunipun, aja taha amituturi, kang marang karaharjan 
Mulai sekarang sampai nanti, aku titip semua adikmu, Prangwadana beserta saudaranya, jagalah keselamatannya, jangan ragu-ragu menasehati demi kesejahteraanya.

Bentuk pengasuhan saudara muda oleh saudara tua sesuai dari data di atas meliputi: pertama, saudara tua mempunyai kewajiban untuk menjaga keselamatan adik-adiknya; dan kedua, saudara tua mempunyai kewajiban memberikan- nasehat kepada adikadiknya agar marnpu menata masa depannya sehingga kelak hidupnya dapat sejahtera. Pembagian tanggung jawab ini sangat bagus agar masa depan seluruh keluarga serta kepribadiannya dapat terbina dengan baik. Selain itu hubungan antar anggota keluargapun tetap harmonis, meskipun orang tua sudah tidak ada. Saudara muda merasa terlindungi dan hidup penuh dengan limpahan kasih sayang dari saudara tua sebagai pengganti orang tua.

\section{Kesimpulan dan Saran \\ 1. Kesimpulan}

Berdasarkan basil penelitian dan pembahasan yang dilakukan, pola asuh anak dalam Serat Paliatma dapat digolongkan menjadi dua, yaitu: pola asuh anak yang berkaitan dengan normanorr6a agama dan pola asuh anak yang berkaitan dengan nilai-nilai hidup.

Pola asuh anak yang berkaitan dengan norma-norma agama meliputi: narima ing pandum, bersyukur, dan bertakwa. Sedangkan pola asuh anak yang berkaitan dengan nilaii-nilai hidup meliputi: laku prihatin, kasih sayang, kerukunan,- icetaatan, berbakti pada negara, dan bertanggung jawab.

\section{Saran}

Serat Paliatma merupakan salah satu serat wulang yang merupakan bagian dari kumpulan karangan pilihan karya KGPAA Mangkunagara. Serat serat wulang lainnya dalam kumpulan karangan pilihan tersebut masih perlu dikaji lebih lanjut agar dapat dimanfaatkan bagi kehidupan sekarang terutama dalam rangka pembentukan kepribadian yang luhur bagi generasi muda.

Hasil penelitian ini supaya dapat dimanfaatkan oleh orang tua sebagai sarana memahami isi dan pesan yang terkandung dalam Serat Paliatma khususnya yang berkaitan dengan pola asuh anak yang ditampilkan melalui nasehatnasehat Mangkunagara IV yang tertuang dalam karya tersebut.

\section{Daftar Pustaka}

Aliyah, R. 1987. Peranan Pola Asuh Orang Tua terhadap Kepemimpinan Remaja. Yogyakarta: FPIPS IKIP Yogyakarta

Baroroh, S. 1985. Pengantar Teori Filologi. Jakarta: Pusat Pembinaan dan Pengembangan Bahasa Depdikbud.

Bratawidjaja, T. M. 1997. Mengungkap dan Mengenal Budaya Jawa. Jakarta: Pradnya Paramita

Faried, M. 1980. Menuju Keluarga Bahagia dan Sejahtera. Bandung: Offset

Furchan, A. 1982. Pengantar Penelitian dalam Pendidikan. Surabaya: Usaha Nasional

Kamajaya. 1992. Karangan Pilihan Anggitan KGPAA Mangkunagara IV. Yogyakarta: Yayasan Centhini

Mangkunagara IV. 1953. Serat-Serat Anggitan Dalem Kanjeng Gusti Pangeran Adipati Arya Mangkunagara IV Jilid III. Jakarta: Nurhopkolep

Marsono. 1999. Ensiklopedia Kebudayaan Jawa. Yogyakarta: Lembaga Studi Jawa

Nurgiyantoro, B. 1998. Teori Pengkajian Fiksi. Yogyakarta: Gadjah Mada University Press

Padmopuspita, A. 1990. "Citra Wanita dalam Sastra" (Cakrawala Pendidikan Edisi Khusus, Th. IX Mei, hal. 39) 
Simanjuntak. 1978. Latar Belakang Kenakalan Remaja. Bandung: Alumni

Suparto, dkk. 1990. Pola Pengasuhan Anak secara Tradisional. Yogyakarta: Pusat Pembinaan dan Pengembangan Bahasa Departemen Pendidikan dan Kebudayaan

Suryadi. L. 1995. Dari Pujangga ke Pengarang Jawa. Yogyakarta: Pustaka Pelajar

Suseno, M. 2001. Etika Jawa. Jakarta: Gramedia Pustaka Utama
1987. Etika Jawa dalam Tantangan. Jakarta: Djambata

Suwondo, T. dkk. 1994. Nilai-Nilai Budaya Susastra Jawa. Jakarta: Pusat Pembinaan dan Pengembangan Bahasa Departemen Pendidikan dan Kebudayaan

Sutjiatiningsih, dkk. 1999. Transliterasi, Terjemahan dan Kajian Nilai Budaya Hikayat Lima Tumenggung. Jakarta: CV Putera Sejati 